\title{
Death Domain Signaling by Disulfide-Linked Dimers of the p75 Neurotrophin Receptor Mediates Neuronal Death in the CNS
}

\author{
Kazuhiro Tanaka, ${ }^{1,2}$ Claire E. Kelly, ${ }^{3}$-Ket Yin Goh, ${ }^{1,2}$ Kim Buay Lim, ${ }^{1,2}$ and Carlos F. Ibáñez ${ }^{1,2,3,4}$ \\ ${ }^{1}$ Department of Physiology, National University of Singapore, Singapore 117597, Singapore, ${ }^{2}$ Life Sciences Institute, National University of Singapore, \\ Singapore 117456, Singapore, ${ }^{3}$ Department of Neuroscience, Karolinska Institute, Stockholm S-17177, Sweden, and ${ }^{4}$ Stellenbosch Institute for Advanced \\ Study, Wallenberg Research Centre at Stellenbosch University, Stellenbosch 7600, South Africa
}

The p75 neurotrophin receptor ( $\mathrm{p} 75^{\mathrm{NTR}}$ ) mediates neuronal death in response to neural insults by activating a caspase apoptotic pathway. The oligomeric state and activation mechanism that enable $\mathrm{p} 75^{\mathrm{NTR}}$ to mediate these effects have recently been called into question. Here, we have investigated mutant mice lacking the $\mathrm{p} 5^{\mathrm{NTR}}$ death domain (DD) or a highly conserved transmembrane (TM) cysteine residue $\left(\mathrm{Cys}^{259}\right.$ ) implicated in receptor dimerization and activation. Neuronal death induced by proneurotrophins or epileptic seizures was assessed and compared with responses in $\mathrm{p} 75^{\mathrm{NTR}}$ knock-out mice and wild-type animals. Proneurotrophins induced apoptosis of cultured hippocampal and cortical neurons from wild-type mice, but mutant neurons lacking p $75^{\mathrm{NTR}}$, only the $\mathrm{p} 75^{\mathrm{NTR}} \mathrm{DD}$, or just Cys ${ }^{259}$ were all equally resistant to proneurotrophin-induced neuronal death. Homo-FRET anisotropy experiments demonstrated that both NGF and proNGF induce conformational changes in $\mathrm{p} 75^{\mathrm{NTR}}$ that are dependent on the TM cysteine. In vivo, neuronal death induced by pilocarpine-mediated seizures was significantly reduced in the hippocampus and somatosensory, piriform, and entorhinal cortices of all three strains of $\mathrm{p} 75^{\mathrm{NTR}}$ mutant mice. Interestingly, the levels of protection observed in mice lacking the DD or only Cys ${ }^{259}$ were identical to those of $\mathrm{p} 75^{\mathrm{NTR}}$ knock-out mice even though the $\mathrm{Cys}^{259}$ mutant differed from the wild-type receptor in only one amino acid residue. We conclude that, both in vitro and in vivo, neuronal death induced by $\mathrm{p} 75^{\mathrm{NTR}}$ requires the DD and TM Cys ${ }^{259}$, supporting the physiological relevance of DD signaling by disulfide-linked dimers of $\mathrm{p} 75^{\mathrm{NTR}}$ in the CNS.

Key words: apoptosis; disulfide bond; epilepsy; neurotrophins; seizures

Significance Statement

A detailed understanding of the physiological significance of distinct structural determinants in the p75 neurotrophin receptor $\left(\mathrm{p} 75^{\mathrm{NTR}}\right.$ ) is crucial for the identification of suitable drug targets in this receptor. We have tested the relevance of the $\mathrm{p} 75^{\mathrm{NTR}}$ death domain (DD) and the highly conserved transmembrane residue Cys ${ }^{259}$ for the ability of p $75^{\mathrm{NTR}}$ to induce apoptosis in neurons of the CNS using gene-targeted mutant mice. The physiological importance of these determinants had been contested in some recent in vitro studies. Our results indicate a requirement for DD signaling by disulfide-linked dimers of $\mathrm{p}^{\mathrm{NTR}}{ }^{\mathrm{NTR}}$ for neuronal death induced by proneurotrophins and epileptic seizures. These new mouse models will be useful for clarifying different aspects of p $75^{\text {NTR }}$ physiology.

\section{Introduction}

In the adult nervous system, signaling pathways that are normally only functional during development often become reactivated

\footnotetext{
Received Dec. 20, 2015; revised April 11, 2016; accepted April 12, 2016.

Author contributions: K.T. and C.F.I. designed research; K.T., C.E.K., K.Y.G., and K.B.L. performed research; K.T., C.E.K., and C.F.I. analyzed data; K.T. and C.F.I. wrote the paper.

This work was supported by the National Medical Research Council of Singapore (Grant CBRG13nov012), the Ministry of Education of Singapore (Grant MOE2014-T2-1-120), the National University of Singapore (Start-Up and Strategic ODPRT Awards), the European Research Council (Grant 339237-p75ntr), the Swedish Research Council (Grant K2012-63X-10908-19-5), the Swedish Cancer Society (Grant 13-0676), and the Knut and Alice Wallenberg Foundation (Grant KAW 2012.0270). We thank Wilma Friedman for reading and commenting on the manuscript.
}

after neural injury. Some of these pathways have neuroprotective or neuroregenerative functions and may represent a self-defense response to the ensuing damage. Other pathways, however, appear to amplify neural damage. As with inflammatory responses, induction of such pathways may have evolved as a mechanism for clearing damage produced after a lesion or insult to cellular ele-

The authors declare no competing financial interests.

Correspondence should be addressed to Carlos F. Ibáñez, Life Sciences Institute, National University of Singapore, 28 Medical Drive, Singapore 117456, Singapore. E-mail: phscfi@nus.edu.sg.

DOI:10.1523/JNEUROSCI.4536-15.2016

Copyright $\odot 2016$ the authors $\quad 0270-6474 / 16 / 365587-09 \$ 15.00 / 0$ 
ments of the nervous system (Ibáñez and Simi, 2012). However, after severe insult, these pathways can do more damage than good. Expression of the p75 neurotrophin receptor ( $\left.\mathrm{p} 75^{\mathrm{NTR}}\right)$ increases markedly after neural injury in many of the same cell types that express $\mathrm{p} 75^{\mathrm{NTR}}$ during development and $\mathrm{p} 75^{\mathrm{NTR}}$ signaling can contribute to neuronal death, axonal degeneration, and dysfunction during injury and cellular stress (Ibáñez and Simi, 2012). Inhibition of $\mathrm{p} 75^{\mathrm{NTR}}$ signaling has therefore emerged as an attractive strategy for limiting neural damage in neurodegeneration and nerve injury. p $75^{\text {NTR }}$ can interact with all members of the neurotrophin family, including mature neurotrophins such as nerve growth factor (NGF) and brain-derived neurotrophic factor (BDNF) and their propeptide forms, such as proNGF and proBDNF, as well as other ligands unrelated to the neurotrophins, such as Nogo and $\beta$-amyloid (for review, see Underwood and Coulson, 2008). Proneurotrophins are potent inducers of neuronal death (Lee et al., 2001; Nykjaer and Willnow, 2012). Expression of proneurotrophins has been reported to be elevated in neurodegenerative conditions and after neural insults (Volosin et al., 2008; Iulita and Cuello, 2014).

The cytoplasmic domain of $\mathrm{p} 75^{\mathrm{NTR}}$ contains a C-terminal death domain (DD) similar to that found in other members of the tumor necrosis factor receptor superfamily (Liepinsh et al., 1997). The DD is linked to the transmembrane (TM) domain by a flexible juxtamembrane region. Studies in cultured primary neurons have implicated both the DD (Charalampopoulos et al., 2012) and the juxtamembrane domain (Coulson et al., 2000) in p75 ${ }^{\mathrm{NTR}}$ mediated cell death. However, the necessity or sufficiency of these receptor domains for $\mathrm{p} 75^{\mathrm{NTR}}$-mediated neuronal death in vivo is unclear.

Neurotrophins and proneurotrophins are dimeric ligands and form twofold symmetry complexes with dimers of the $\mathrm{p} 75^{\mathrm{NTR}}$ extracellular domain in $\mathrm{x}$-ray crystal structures (Aurikko et al., 2005; Gong et al., 2008; Feng et al., 2010). In addition, we have shown recently that the $\mathrm{p} 75^{\mathrm{NTR}} \mathrm{DD}$ can form low-affinity symmetric dimers in solution (Lin et al., 2015). In intact cells, p75 NTR can also form dimers in the absence of ligands through both covalent and noncovalent interactions. A highly conserved Cys residue in the $\mathrm{p} 75^{\mathrm{NTR}} \mathrm{TM}$ domain stabilizes the formation of covalent $\mathrm{p} 75^{\text {NTR }}$ dimers through disulfide bonding (Vilar et al., 2009; Sykes et al., 2012). FRET experiments have shown that the two DDs in the $\mathrm{p} 75^{\mathrm{NTR}}$ dimer are in close proximity to each other (high FRET state) and that NGF binding induces oscillations
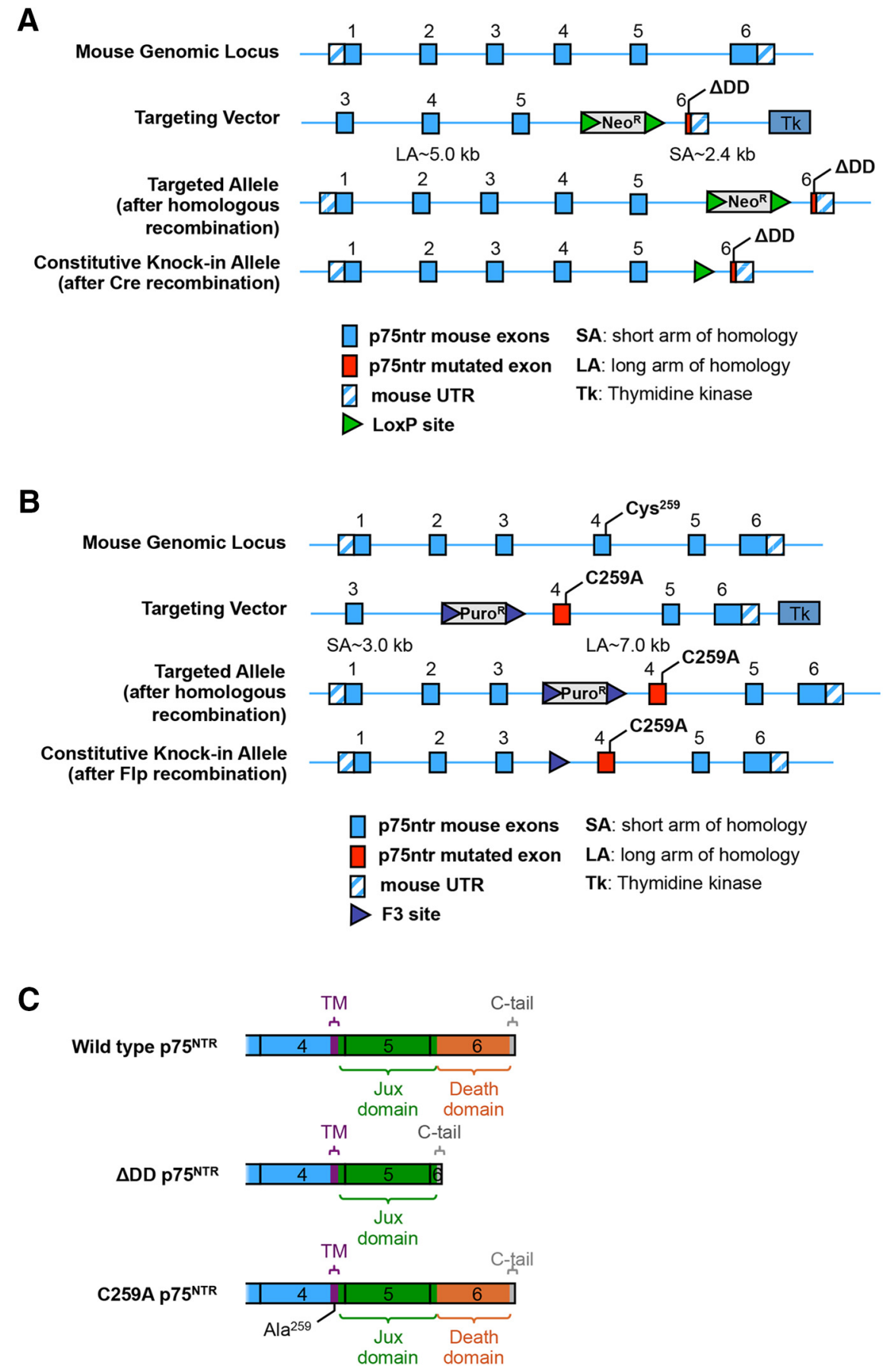

Figure 1. Generation of knock-in alleles of $p 75^{\mathrm{NTR}}$ lacking the DD or TM cysteine Cys ${ }^{259}$. A, Schematic of the $p 75$ ntr locus (not to scale) with strategy for generation of the $\triangle D D$ mutant allele. $B$, Schematic of the $p 75 n$ tr locus (not to scale) with strategy for generation of the C259A mutant allele. C, Schematic of C-terminal sequences in wild-type, $\triangle D D$, and C259A p $75^{\text {NTR }}$ proteins. Black lines outline the boundaries of exons 4,5 , and 6 , denoted by their respective numbers. Sequences corresponding to the extracellular, TM, juxtamembrane (Jux), and DDs are colored in blue, purple, green, and orange, respectively. The C-terminal tail containing a putative PDZ-binding motif is in gray. The $\triangle D D$ protein ends in QGDTATSPV, where QGD corresponds to the end of the Jux domain and TATSPV to the C-terminal tail. For the (259A protein, the TGC (Cys) codon was changed to GCA (Ala). Black vertical lines mark the boundaries of exons 4,5 , and 6 . 
A

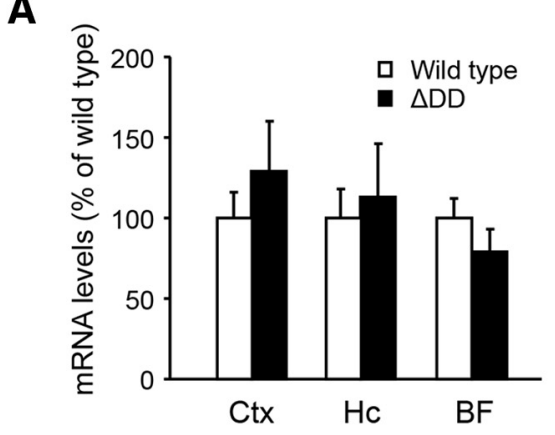

B

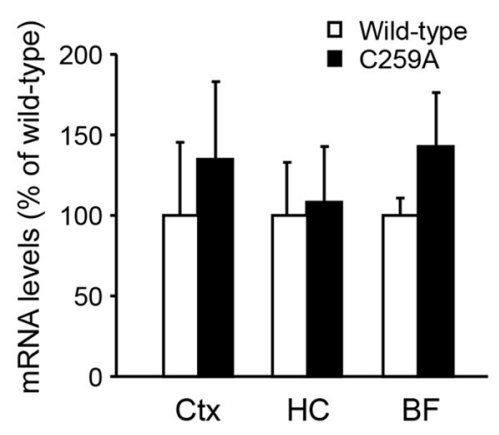

C

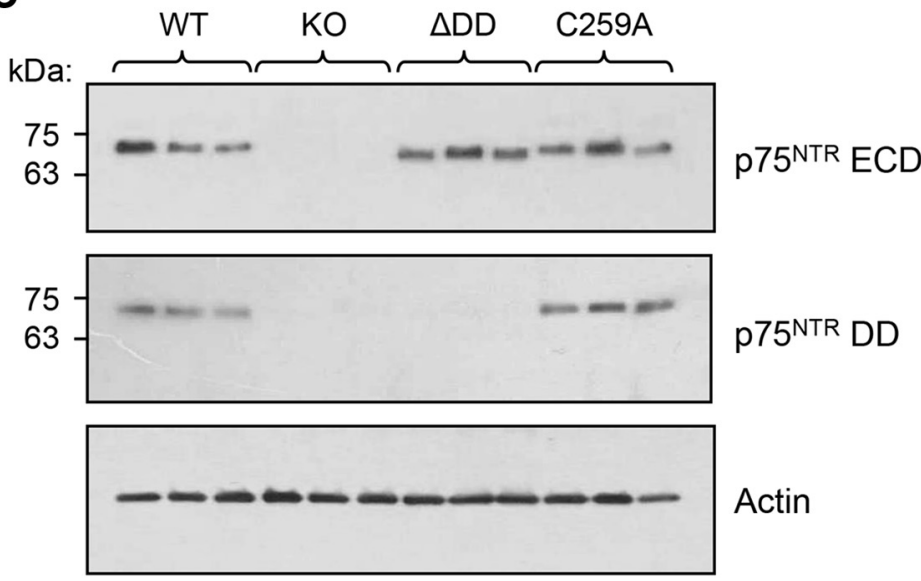

Figure 2. Expression of knock-in alleles of $p 75^{\mathrm{NTR}}$ lacking the DD or TM cysteine Cys ${ }^{259} \cdot \boldsymbol{A}$, Expression of $p 75$ ntr mRNA in cortex (Ctx), hippocampus ( $\mathrm{Hc}$ ), and basal forebrain (BF) of $\mathrm{p} 75^{\mathrm{NTR}}$ wild-type and $\triangle \mathrm{DD}$ adult mice as assessed by quantitative PCR. For each brain region, expression was normalized to actin mRNA levels. Error bars indicate average (relative to wild-type levels) \pm SD of triplicate determinations ( $n=3$ different animals from each genotype). $\boldsymbol{B}$, Expression of $p 75 n t r \mathrm{mRNA}$ in $\mathrm{Ctx}$, $\mathrm{Hc}$, and BF of p75 ${ }^{\text {NTR }}$ wild-type and (259A adult mice as assessed by quantitative PCR. For each brain region, expression was normalized to actin mRNA levels. Error bars indicate average (relative to wild-type levels) \pm SD of triplicate determinations ( $n=3$ different animals from each genotype). C, Expression of $\mathrm{p} 75^{\mathrm{NTR}}$ in cerebral cortex of 3-month-old wild-type (WT) knock-out (K0), $\triangle \mathrm{DD}$ and (259A mice analyzed by Western blotting $(n=3)$. ECD, Antibody against extracellular domain; $\mathrm{DD}$, antibody against $\mathrm{DD}$. Ten micrograms of total protein extract was loaded in each lane. Reprobing with $\beta$-actin antibodies is shown as a loading control.

cysteine (Anastasia et al., 2015). Based on molecular weights estimated from SDS/PAGE gels and overexpression of $\mathrm{p} 75^{\mathrm{NTR}}$ constructs in cultured cells, those investigators argued that $\mathrm{p} 75^{\mathrm{NTR}}$ mainly exists as an inactive trimer and that neurotrophins induce biological activities through monomeric $\mathrm{p} 75^{\mathrm{NTR}}$ independently of the conserved TM cysteine.

Here, we report the generation of two new mouse models, lacking the $\mathrm{p} 75^{\mathrm{NTR}} \mathrm{DD}$ or the conserved TM cysteine, respectively, generated by homologous recombination. We assessed neuronal death induced by proneurotrophin ligands in neuronal cultures or by epileptic seizures in vivo compared with p $75^{\text {NTR }}$ knock-out and wild-type animals. Our results support the physiological relevance of DD signaling by dimers of p $75^{\text {NTR }}$ in the CNS.

\section{Materials and Methods}

Animals. Mice were housed in a $12 \mathrm{~h}$ light/dark cycle and fed a standard chow diet. The following transgenic mouse lines were used: $p 75^{\text {NTR }}$ knock-out mice (Lee et al., 1994), p $75^{\mathrm{NTR}} \Delta \mathrm{DD}$ knock-in mice (this study), and p $75^{\text {NTR }}$ C259A knock-in mice (this study). All mouse lines used in this study were backcrossed to the C57BL/6J background. Epilepsy studies were performed on male mice. For neuronal cultures, embryos of either sex were used. The $\Delta \mathrm{DD}$ targeting vector was generated by A. Simi (Karolinska Institutet) using Sv129 genomic fragments from the p75ntr locus and transfected into Sv129 ES cells. The coding sequence of the $\triangle \mathrm{DD}$ allele ends in QGDTATSPV, where QGD corresponds to the end of the Jux domain and TATSPV to the C-terminal tail. The C-terminal SPV motif has been proposed to interact with PDZ domains (Roux and Barker, 2002). Gene-targeted $\triangle D D$ mice were generated at the Karolinska Center for Transgene Technologies using standard methods. The C259A targeting vector was generated using BAC clones from the C57BL/6J RPCIB-731 BAC library and transfected into TaconicArtemis C57BL/6N Tac ES cell line. The TGC (Cys) codon was changed to GCA (Ala). Genetargeted C259A mice were generated at TaconicArtemis using standard methods. Animal experiments were approved by the Institutional Animal Care and Use Committee of the National University of Singapore.

Tissue isolation, RNA preparation, and quantitative PCR. Total mRNA was isolated from cortex, hippocampus, and basal forebrain from mouse brains using the RNeasy Mini Kit (Qiagen) according to the manufacturer's protocol. cDNA was synthesized by reverse transcription using the Omniscript RT kit (Qiagen). Real-time PCR was conducted using the 7500 Real-Time PCR system (Applied Biosystems) with SYBR Green fluorescent probes. The following primer pairs were used: $775^{\mathrm{NTR}}, 5^{\prime}$ GTTCTCCTGCCAGGACAAACAGAACAC-3' and $5^{\prime}$-GCATTCGGCGTCAGCCCAGGGCGT GCA-3'; $\beta$-actin, $5^{\prime}$-GCTCTTTTCCAGCCTTCCTT-3' and 5'-AGTACTTGCGCTCAGAGGA- ${ }^{\prime}$. As a standard for assessment of copy number of PCR products, serial concentrations of each PCR fragment were amplified in the same manner. The amount of cDNA was calculated as the copy numbers in each reverse transcription product and normalized to $\beta$-actin values.

Western blotting. Mouse cerebral cortex was dissected, snap-frozen, and homogenized in RIPA lysis buffer supplemented with protease inhibitor mixture (Roche). Samples were centrifuged at $12,000 \times g$ and the supernatants were used. The protein concentration was determined using the Pierce BCA protein assay kit. Proteins $(20 \mu \mathrm{g})$ were applied to $8 \%$ SDS-polyacrylamide gel under reducing conditions and electrotransferred to a PVDF membrane. Immunoblots were performed using antibodies specific for $\mathrm{p} 75^{\mathrm{NTR}}$ extracellular domain (ECD) (1:2000, GT15057; Neuromics), p75 ${ }^{\text {NTR }}$ DD (1:500, ab52987; Abcam), and $\beta$-actin (1:4000; A2668; Sigma-Aldrich). Immunoblots were developed using the SignalFire ECL reagent (Cell Signaling Technology) and exposed to $\mathrm{x}$-ray films (Konica Minolta). x-ray films were digitally scanned and image analysis and quantification of band intensities were done with ImageJ.

Primary culture of hippocampal and cortical neurons and assessment of neuronal death. Primary neurons were isolated from mouse embryonic brain at embryonic day 17.5 (E17.5). The cortical or hippocampal tissue was dissected and dissociated by trypsin digestion and trituration in serum-free medium. Cells were counted by hemocytometer and seeded at a density of $8 \times 10^{4}$ cells per well in 24 -well plates on poly-lysinecoated glass slides. They were maintained in Neurobasal medium supplemented with B27 (Invitrogen), Glutamax (Invitrogen), and penicillin/streptomycin at $37^{\circ} \mathrm{C}$ with $5 \% \mathrm{CO}_{2}$. After $3 \mathrm{~d}$ in vitro, cultures were treated for $12 \mathrm{~h}$ (for caspase-3) or $24 \mathrm{~h}$ (for propidium iodide) with 20 $\mathrm{ng} / \mathrm{ml}$ proNGF or proBDNF (Alomone). Neuronal apoptosis was assessed by immunocytochemistry of activated caspase- 3 and by staining with propidium iodide. For assessment of activated caspase-3, cells were fixed with acetone-methanol, permeabilized with $0.5 \%$ Triton X-100, and blocked in $10 \%$ normal donkey serum. Fixed cells were then incubated at $4^{\circ} \mathrm{C}$ overnight with anti-cleaved-caspase-3 (1:200; Cell Signaling 
A

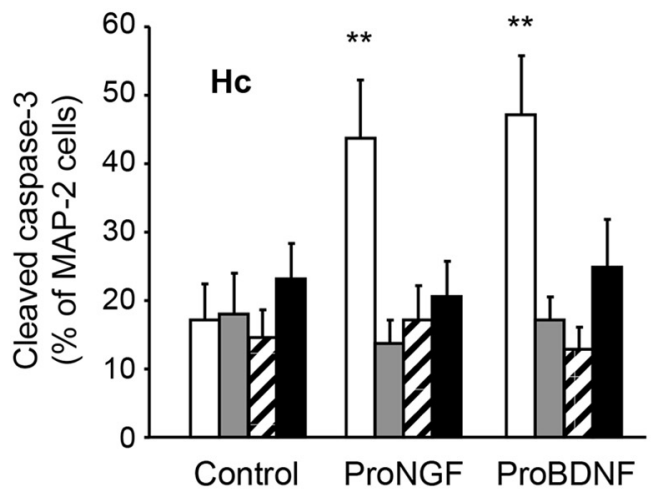

C

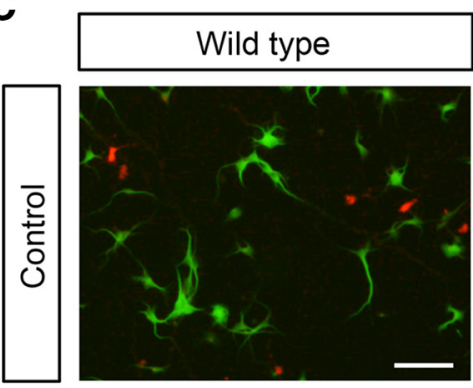

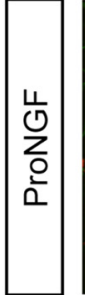

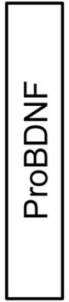

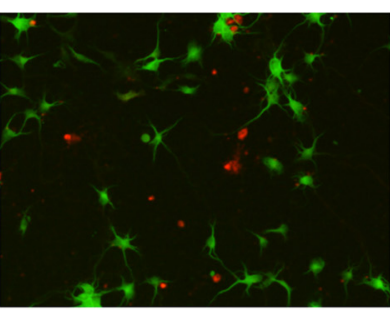

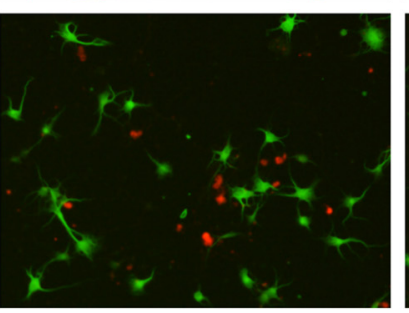

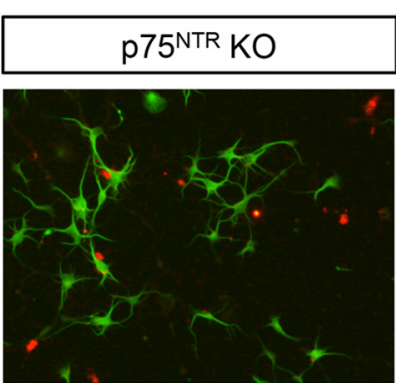
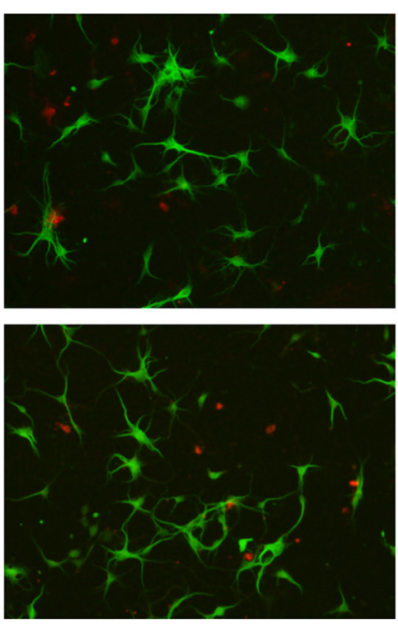

B

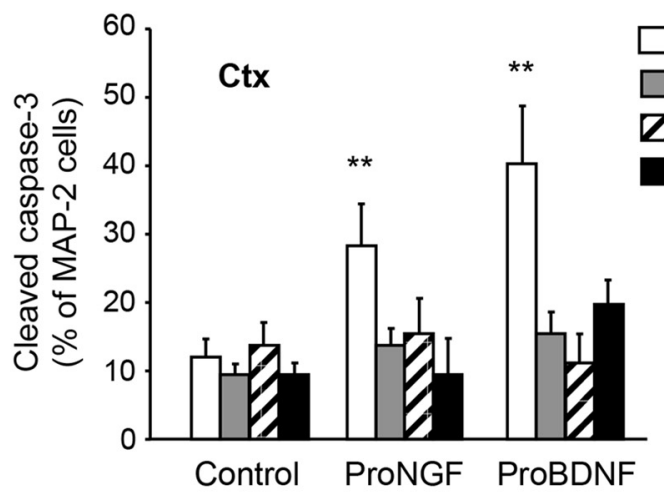

Wild type p75 NTR KO p75 NTR $\triangle D D$ p $75^{\text {NTR }}$ Cys ${ }^{259}$
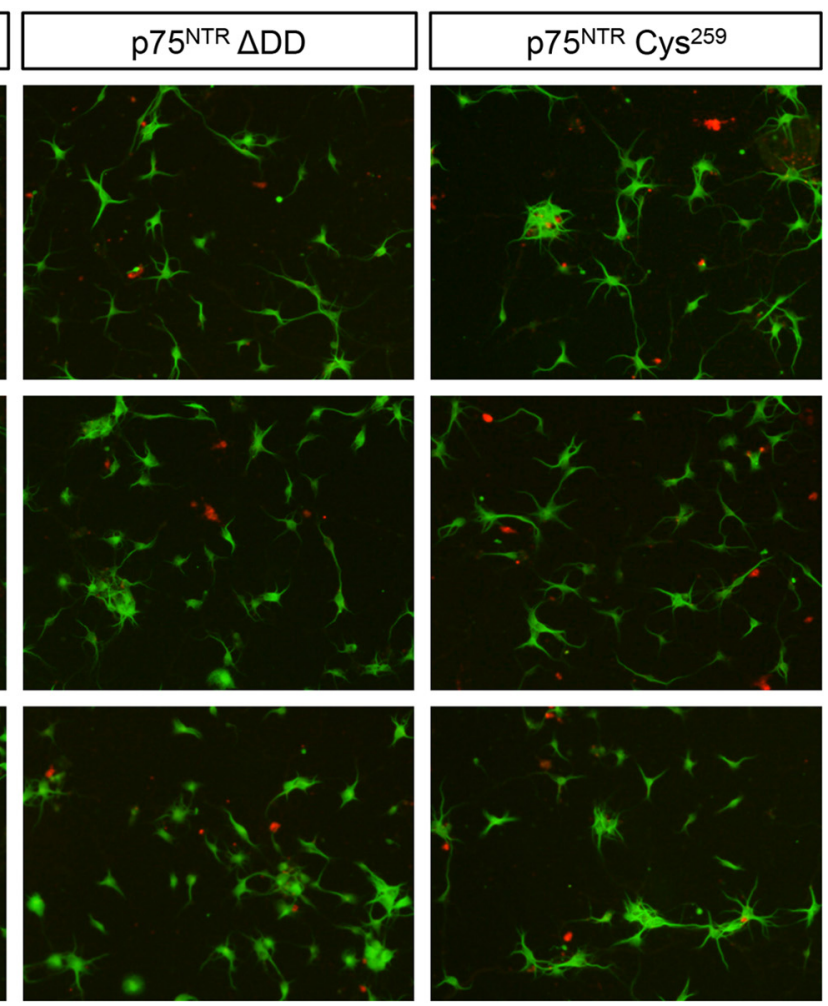

Figure 3. Induction of caspase-3 activation by proneurotrophins requires the $\mathrm{p} 75^{\mathrm{NTR}} \mathrm{DD}$ and TM Cys ${ }^{259}$. $\boldsymbol{A}$, Activation of caspase-3 by $12 \mathrm{~h}$ treatment with proNGF or proBDNF in cultured embryonic hippocampal (Hc) neurons identified by MAP-2 staining, from p $75^{\mathrm{NTR}}$ wild-type, knock-out (KO), $\triangle \mathrm{DD}$, and $(259 \mathrm{~A}$ mice. Error bars indicate average $\pm \mathrm{SD}$ of three independent determinations. ${ }^{* *} p<0.01$ versus control. $B$, Activation of caspase- 3 by $12 \mathrm{~h}$ treatment with proNGF or proBDNF in cultured embryonic cortical (Ctx) neurons identified by MAP-2 staining, from p75 ${ }^{\text {NTR }}$ wild-type, K0, $\triangle D D$, and C259A mice. Error bars indicate average $\pm S D$ of three independent determinations. ${ }^{* *} p<0.01$ versus control. $C$, Representative photomicrographs of immunofluorescence staining for cleaved caspase-3 (red) and MAP-2 (green) in cultured cortical neurons. Scale bar, $50 \mu \mathrm{m}$.

Technology) and monoclonal anti-MAP-2 (1:4000; Abcam) antibodies, followed by incubation with fluorophore-conjugated secondary antibodies. Cleaved caspase-3-positive cells among the MAP2positive cell population were counted in three random fields per well from triplicate wells at a $20 \times$ magnification. Evaluation of pyknotic nuclei was performed by propidium iodide staining in cultures that that had been treated for $24 \mathrm{~h}$ with $20 \mathrm{ng} / \mathrm{ml}$ proNGF. Cells were incubated with propidium iodide at a final concentration of $20 \mu \mathrm{g} / \mathrm{ml}$ for $30 \mathrm{~min}$ at $37^{\circ} \mathrm{C}$ before fixation in $4 \% \mathrm{PFA} / 4 \%$ sucrose, followed by overnight staining with anti-Tuj1 antibodies (1:1000; Sigma-Aldrich) and DAPI counterstaining. Cells showing pyknotic nuclei among the Tuj1-positive cell population were counted in 30 images per coverslip $(\approx 250-600$ neurons per coverslip) from triplicate wells at a $20 \times$ magnification. The experiments were performed two times with similar results. Approximately $95 \%$ of neurons stained with cleaved caspase- 3 also stained with propidium iodide. Conversely, $\sim 67 \%$ of neurons positive for propidium iodide also stained for cleaved caspase-3.
Homo-FRET anisotropy microscopy. Anisotropy microscopy was done as described previously (Vilar et al., 2009) in transiently transfected COS-7 cells. Images were acquired $24 \mathrm{~h}$ after transfection using a Nikon Eclipse Ti-E motorized inverted microscope equipped with an X-Cite LED illumination system. A linear dichroic polarizer (Meadowlark Optics) was placed in the illumination path of the microscope and two identical polarizers were placed in an external filter wheel at orientations parallel and perpendicular to the polarization of the excitation light, respectively. The fluorescence was collected via a CFI Plan Apochromat Lambda $40 \times, 0.95$ numerical aperture air objective and parallel and polarized emission images were acquired sequentially on an Orca CCD camera (Hamamatsu Photonics). Data acquisition was controlled by the MetaMorph software (Molecular Devices). NGF, proNGF (both from Alomone Labs), or vehicle was added $3 \mathrm{~min}$ after the start of the time lapse at a concentration of 100 and $20 \mathrm{ng} / \mathrm{ml}$, respectively. Anisotropy values were extracted from image stacks of 30 images acquired in both parallel and perpendicular emission modes every $30 \mathrm{~s}$ for a time period of $15 \mathrm{~min}$ after ligand addition. For each construct, 25-30 ROIs were mea- 
A

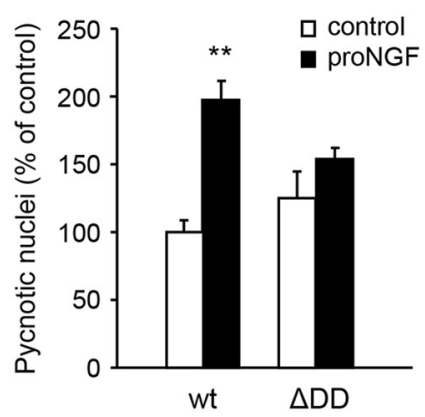

C
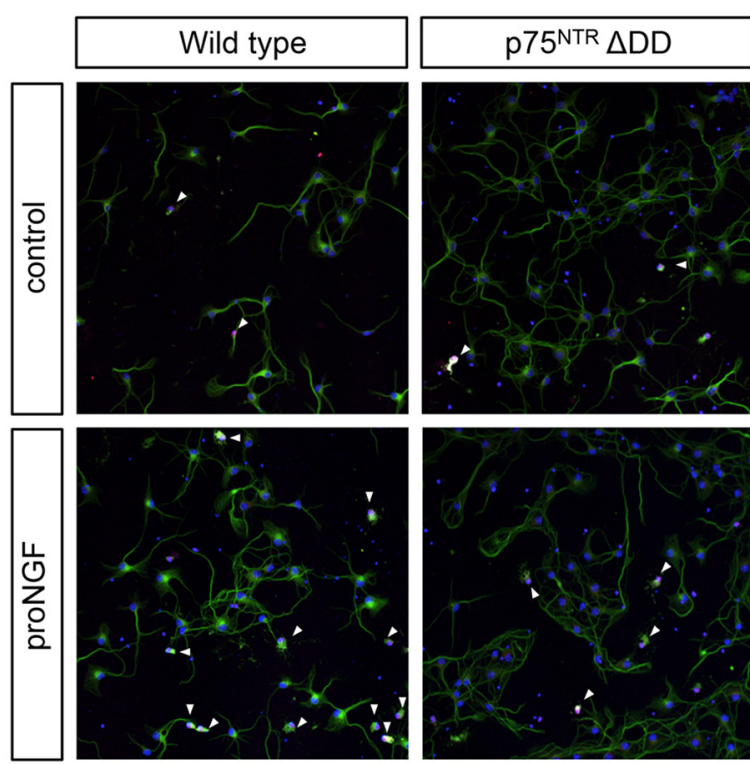

B
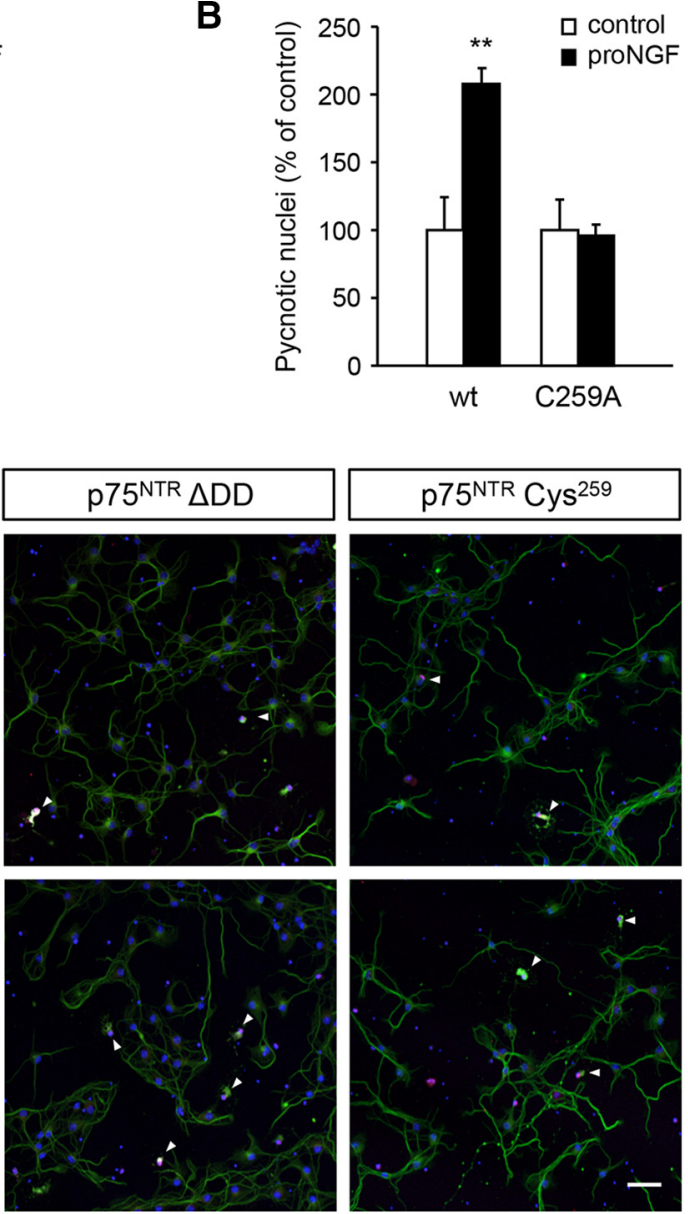
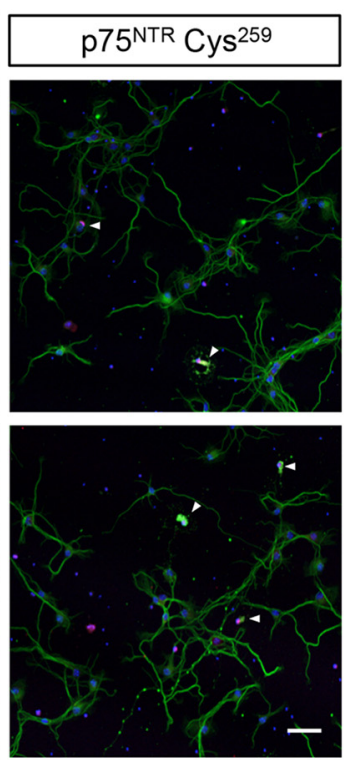

Figure 4. Neuronal death induced by proNGF requires $\mathrm{p} 75^{\mathrm{NTR}}$ DD and TM Cys ${ }^{259}$. A, Pyknotic nuclei identified by propidium iodide staining after $24 \mathrm{~h}$ treatment with proNGF in cultured embryonic hippocampal neurons identified by Tuj1 staining and counterstained with DAPI, from p75 NTR wild-type and $\triangle \mathrm{DD}$ mice. Error bars indicate average percentage of control \pm SEM. ${ }^{* *} p<$ 0.01 versus control $(n=6)$. B , Pyknotic nuclei identified by propidium iodide staining after $24 \mathrm{~h}$ treatment with proNGF in cultured embryonic hippocampal neurons identified by Tuj1 staining and counterstained with DAPI from p $75^{\text {NTR }}$ wild-type and C259A mice. Error bars indicate average percentage of control $\pm S E M .{ }^{* *} p<0.01$ versus control $(n=3)$. C, Representative photomicrographs of pyknotic nuclei (red), denoted by arrowheads, and Tuj1 staining (green) in cultured hippocampal neurons counterstained with DAPI (blue). Scale bar, $50 \mu \mathrm{m}$.

sured in three independent transfections performed in duplicate. Fluorescence intensity and anisotropy images were calculated as described by Squire et al. (2004). Wild-type and C257A mutant cDNA constructs of rat $\mathrm{p} 75^{\mathrm{NTR}}$ were tagged at the $\mathrm{C}$ terminus with a monomeric version of EGFP (Clontech) carrying the A206K mutation that disrupts EGFP dimerization as described previously (Vilar et al., 2009).

Induction of epileptic seizures by pilocarpine injection. Treatment of adult mice began with injection of methyl-scopolamine $(1 \mathrm{mg} / \mathrm{kg}$, s.c.; Sigma-Aldrich) and phenytoin ( $50 \mathrm{mg} / \mathrm{kg}$, s.c.; Sigma-Aldrich) to reduce peripheral muscarinic effects and mortality associated with tonic seizures, respectively. After $30 \mathrm{~min}$, status epilepticus was induced by injection of pilocarpine $(300 \mathrm{mg} / \mathrm{kg}$, i.p.). Two hours later, status epilepticus was terminated by injection of diazepam $(10 \mathrm{mg} / \mathrm{kg}$, i.p.). Sham-control mice were treated exactly as the pilocarpine-treated animals except that the pilocarpine injection was replaced by saline injection.

Histological studies. Twenty-four hours after pilocarpine or saline injection, mice were anesthetized by pentobarbital and perfused transcardially with $4 \%$ paraformaldehyde followed by decapitation. Brains were harvested, postfixed by $4 \%$ paraformaldehyde, and cryoprotected with $20 \%$ sucrose. Coronal sections $(30 \mu \mathrm{m})$ were cut in a cryostat and processed for TUNEL assay using a kit from Roche following the manufacturer's instructions and for immunohistochemistry with anti-NeuN antibody (1:200; Merck). Sections were taken between bregma $0.26 \mathrm{~mm}$ and $-0.10 \mathrm{~mm}$ for somatosensory cortex and between bregma -1.94 and $-2.18 \mathrm{~mm}$ for hippocampus,

entorhinal cortex, and piriform cortex (Paxinos and Franklin, 2004). TUNEL-positive cells were counted in 3-5 consecutive sections (each corresponding to an area of $\sim 0.25 \mathrm{~mm}^{2}$ ) from each brain and averaged. A total of $10-13$ animals were used per group, as indicated in Figure 5.

Statistical analyses. Statistically significant differences were assessed by two-way ANOVA followed by Student's $t$ test (for cleaved caspase- 3 and propidium iodide data) or Mann-Whitney $U$ test (for TUNEL data).

\section{Results}

Generation and characterization of knock-in alleles of $\mathrm{p} 75^{\mathrm{NTR}}$ lacking the DD or TM cysteine Cys ${ }^{259}$

Alleles of the mouse p75ntr gene lacking sequences encoding the $\mathrm{DD}(\Delta \mathrm{DD})$ or with an alanine substitution of TM residue Cys $^{259}$ (C259A) were generated by homologous recombination in embryonic stem cells (Fig. $1 A, B$ ). To generate the $\triangle \mathrm{DD}$ allele, exon 6 sequences encoding the $\mathrm{p} 75^{\mathrm{NTR}} \mathrm{DD}$ were removed from the targeting construct, leaving the juxtamembrane domain directly upstream of a short C-terminal tail (Fig. 1C) containing a putative PDZ-binding motif (Roux and Barker, 2002). p75 ${ }^{\text {NTR }}$ mRNA expression levels in hippocampus, cerebral cortex, and basal forebrain of young adult mice were indistinguishable in $\triangle \mathrm{DD}$, C259A, and wild-type strains (Fig. 2A,B). In agreement with this, similar $\mathrm{p} 75^{\mathrm{NTR}}$ protein levels were detected in the cerebral cortex of $\triangle \mathrm{DD}, \mathrm{C} 259 \mathrm{~A}$, and wild-type mice as assessed by Western blotting using an antibody directed toward the p75 ${ }^{\text {NTR }}$ ECD (Fig. 2C). As expected, reprobing with antibodies directed toward the p $75^{\text {NTR }}$ DD confirmed the absence of DD sequences in $\triangle \mathrm{DD}$ mice (Fig. $2 C, \mathrm{DD}$ ).

Neuronal death induced by proneurotrophins requires the p75 ${ }^{\text {NTR }}$ DD and TM Cys ${ }^{259}$

Neuronal death induced by proneurotrophin ligands was assessed in cultures of hippocampal and cortical neurons isolated from E17.5 mouse embryos. Previous work showed that hippocampal neurons lacking $\mathrm{p} 75^{\mathrm{NTR}}$ are resistant to neuronal death induced by mature NGF (Troy et al., 2002). Using proNGF and proBDNF, we found that $\mathrm{p} 75^{\mathrm{NTR}}$ knock-out hippocampal and cortical neurons are also resistant to cell death induced by proneurotrophins as assessed by immunocytochemistry for activated caspase-3 (Fig. 3A-C). Interestingly, mutant neurons lacking either the $\mathrm{p} 75^{\mathrm{NTR}} \mathrm{DD}$ or only TM Cys ${ }^{259}$ were equally resistant to proneurotrophin-induced cell death as knock-out neurons (Fig. 3A-C). Cell death was also assessed by evaluation of pyknotic nuclei stained by propidium iodide in embryonic hippocampal neurons from $\triangle \mathrm{DD}$ and C259A mutant mice after treatment with proNGF. Mutant neurons were resistant to induction of pyknotic nuclei by proNGF (Fig. $4 A-C$ ). These data indicate that both the $\mathrm{p} 75^{\mathrm{NTR}} \mathrm{DD}$ and TM Cys ${ }^{259}$ are required for neuronal death induced by proneurotrophins. 
A

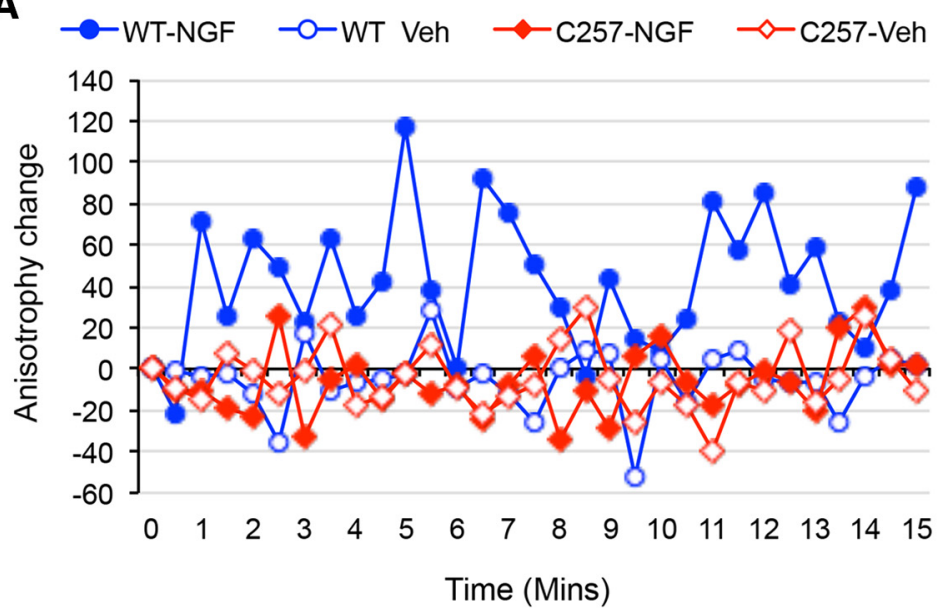

C

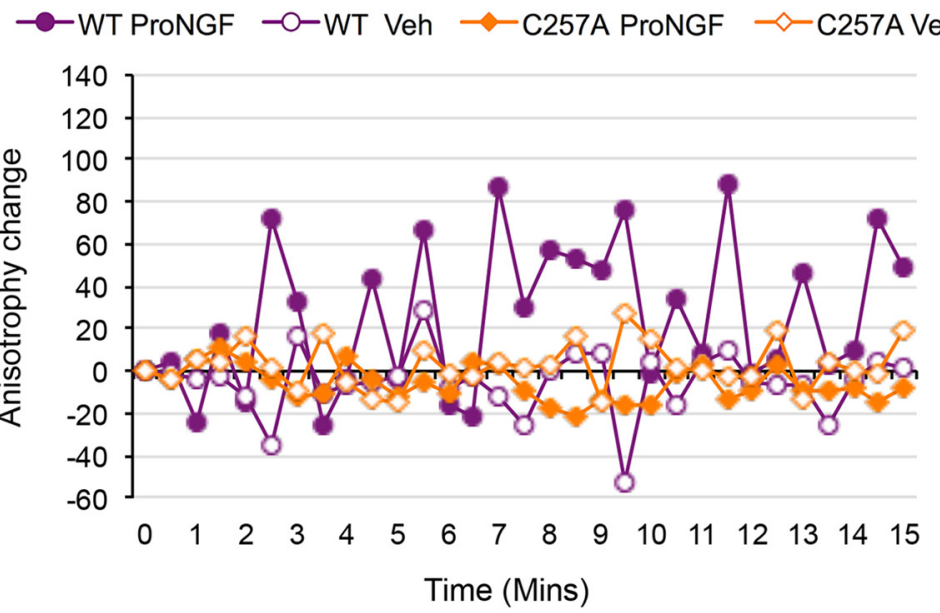

B

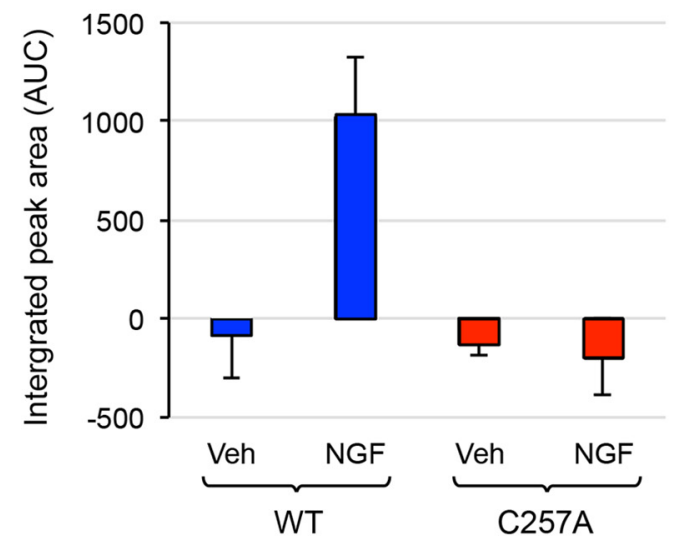

D

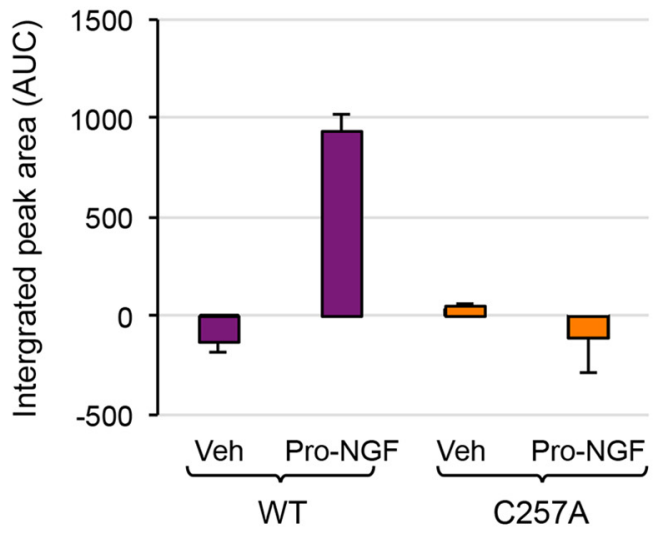

Figure 5. NGF and proNGF induce conformational changes in $p 75^{\mathrm{NTR}}$ that are dependent on the conserved TM cysteine. $A$, Representative experiment showing traces of average anisotropy change after addition of NGF or vehicle in cells expressing wild-type or $2257 \mathrm{~A} \mathrm{rat} \mathrm{p} 75^{\mathrm{NTR}}$. Addition of NGF, but not vehicle, induced positive anisotropy oscillations above baseline (horizontal axis at 0) that were abolished in the (257A mutant. $B$, Net anisotropy change over 15 min after addition of NGF or vehicle in cells expression wild-type or C $257 \mathrm{~A} \mathrm{p} 75^{\mathrm{NTR}}$. Results are expressed as average \pm SD ( $n=3$ experiments; $n=15-17$ cells examined per experiment). AUC, Area under curve. ${ }^{* *} p<0.001$ versus vehicle. C, Representative experiment showing traces of average anisotropy change after addition of proNGF or vehicle in cells expressing wild-type or $\left(257 \mathrm{~A}\right.$ rat $\mathrm{p} 75^{\mathrm{NTR}}$. Addition of proNGF induced positive anisotropy oscillations above baseline (horizontal axis at 0 ) that were abolished in the C257A mutant. $\boldsymbol{D}$, Net anisotropy change over $15 \mathrm{~min}$ after addition of proNGF or vehicle in cells of wild-type or C257A p $75^{\text {NTR }}$. Results are expressed as average \pm SD ( $n=3$ experiments; $n=15-17$ cells examined per experiment). ${ }^{* *} p<0.001$ versus vehicle.

NGF and proNGF induce conformational changes in $\mathrm{p} 75^{\mathrm{NTR}}$ that are dependent on conserved TM cysteine residue

In our previous work, we showed that NGF induces a conformational change in $\mathrm{p} 75^{\mathrm{NTR}}$ that is dependent on TM Cys ${ }^{259}$ and results in the separation of the DDs in the $\mathrm{p} 75^{\mathrm{NTR}}$ dimer as measured by homo-FRET anisotropy (Vilar et al., 2009). Given the requirement of $\mathrm{Cys}^{259}$ for the effects of proNGF on neuronal death (Figs. 3, 4), we sought to determine whether this ligand also induces similar conformational changes in $\mathrm{p} 75^{\mathrm{NTR}}$. Real-time homo-FRET anisotropy measurements of DD:DD interaction in response to NGF or proNGF were recorded in COS cells transfected with constructs expressing EGFP-tagged wild-type or C257A mutant rat p $75^{\text {NTR }}$ as described previously (Vilar et al., 2009). (We note that mouse Cys ${ }^{259}$ corresponds to Cys ${ }^{257}$ in rat p $75^{\mathrm{NTR}}$.) Application of NGF produced large oscillations of increased p $75^{\text {NTR }}$ anisotropy at the cell membrane (Fig. $5 \mathrm{~A}$ ), resulting in a positive net change integrated over 15 min treatment compared with vehicle (Fig. 5B). Because FRET is inversely related to anisotropy, this indicates ligand-triggered separation of receptor intracellular domains (Vilar et al., 2009). Stimulation with proNGF produced quantitatively similar anisotropy changes in $\mathrm{p} 75^{\mathrm{NTR}}$ (Fig. $5 C, D$ ). Importantly, anisotropy changes in response to either ligand were abolished in the C257A p $75^{\text {NTR }}$ mutant, indicating the requirement of the conserved TM cysteine for activation of $\mathrm{p} 75^{\mathrm{NTR}}$ in response to both mature NGF and proNGF.

Essential role of the $\mathrm{p} 75^{\mathrm{NTR}}$ DD and TM cysteine Cys ${ }^{259}$ in neuronal death induced by pilocarpine-mediated seizures Epileptic seizures induce neuronal death in animal models and human epilepsy. In rodents, seizures elicit $\mathrm{p} 75^{\mathrm{NTR}}$-mediated apoptosis of neurons in several brain areas, including hippocampus, cortex, and basal forebrain (Roux et al., 1999; Troy et al., 2002; Volosin et al., 2006; Unsain et al., 2008; Volosin et al., 2008; VonDran et al., 2014). Epileptic seizures induced by pilocarpine injection elicited apoptosis mainly in neurons, as assessed by overlap between TUNEL and NeuN in sections from the hippocampal formation (Fig. 6A). TUNEL levels in sham-operated animals were very low: between $0 \%$ and $5 \%$ of the those observed after pilocarpine treatment (data not shown). We assessed apoptosis $24 \mathrm{~h}$ after pilocarpine injection in 
A
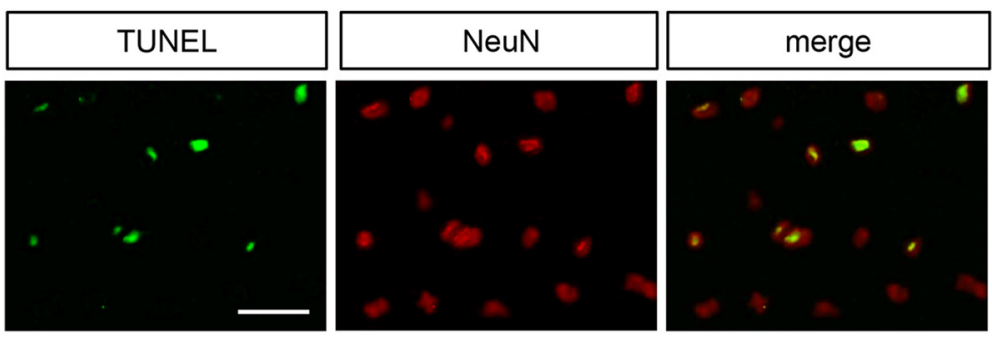

B
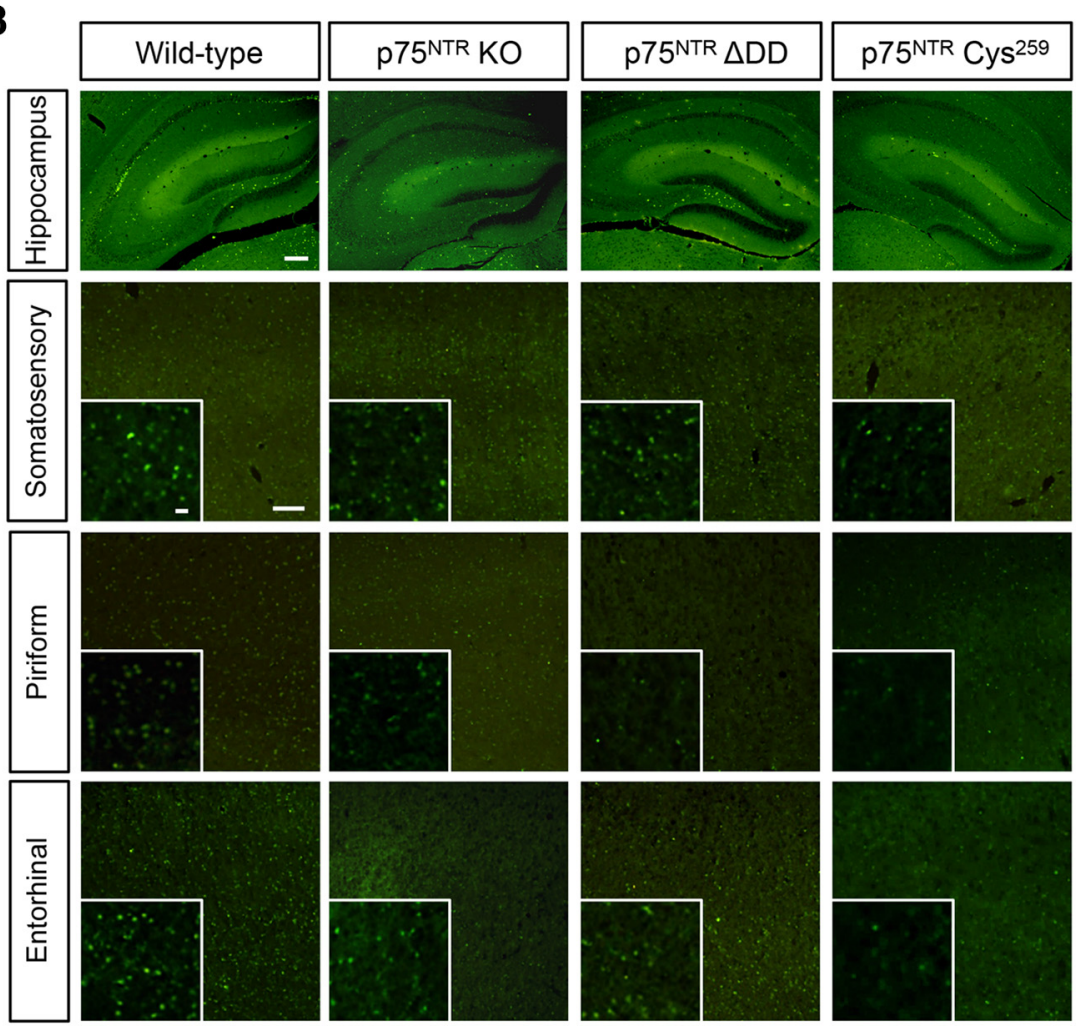

C

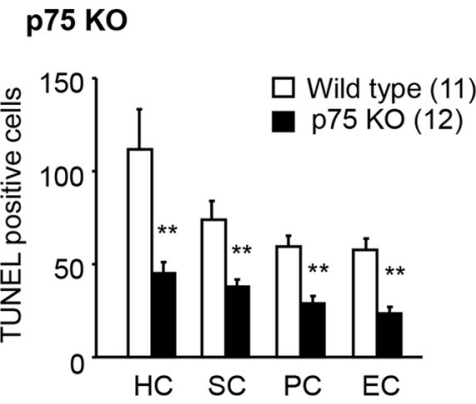

D

\section{p75 $\triangle \mathrm{DD}$}

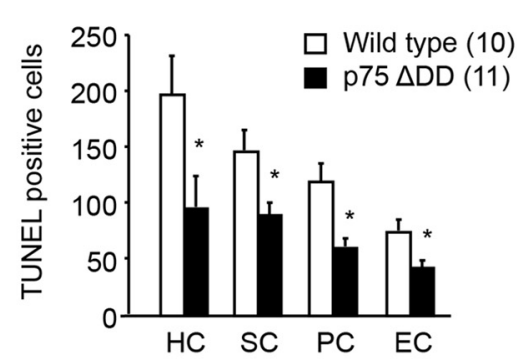

$\mathbf{E}$

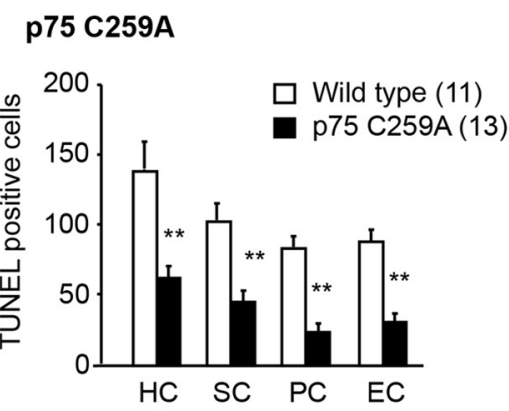

Figure 6. Essential role of the $\mathrm{p} 75^{\mathrm{NTR}} \mathrm{DD}$ and TM cysteine Cys ${ }^{259}$ in cell death induced by pilocarpine-mediated seizures. $A$, TUNEL staining (green) appears mainly on neurons identified by NeuN staining (red) in the hippocampal hilar region of adult wild-type mice $24 \mathrm{~h}$ after pilocarpine-induced seizures. Scale bar, $50 \mu \mathrm{m}$. $\boldsymbol{B}$, Representative photomicrographs of TUNEL staining (green) in hippocampus, somatosensory cortex, piriform cortex, and entorhinal cortex of wild-type, $\mathrm{KO}, \Delta \mathrm{DD}$, and $\mathrm{C} 259 \mathrm{~A}$ mice. Scale bars, $100 \mu \mathrm{m}$, hippocampus; $50 \mu \mathrm{m}$, cortices (5 $\mu \mathrm{m}$, insets). $C$, TUNEL-positive cells in hippocampus (HC), somatosensory cortex (SC), piriform cortex (PC), and entorhinal cortex (EC) of wild-type and p75 NTR K0 mice. Error bars indicate average \pm SEM. The number of animals used in each group is indicated in brackets. ${ }^{* *} p<0.01$ versus wild-type. D, TUNEL-positive cells in HC, SC, PC, and EC of wild-type and p75 ${ }^{\text {NTR }} \Delta$ DD mice. Error bars indicate average \pm SEM. The number of animals used in each group is indicated in brackets. ${ }^{*} p<0.05$ versus wild-type. E, TUNEL-positive cells in $\mathrm{HC}, S C, \mathrm{PC}$, and EC of wild-type and $p 75{ }^{\text {NTR }} \mathrm{C} 259 \mathrm{~A}$ mice. Error bars indicate average \pm SEM. The number of animals used in each group is indicated in brackets. ${ }^{* *} p<0.01$ versus wild-type.

hippocampus as well as somatosensory, piriform, and entorhinal cortices of $\mathrm{p} 75^{\mathrm{NTR}}$ knock-out, $\triangle \mathrm{DD}$, and Cys ${ }^{259}$ mutant mice compared with wild-type controls (Fig. $6 B$ ). In agreement with previous studies (Troy et al., 2002), knock-out mice showed reduced seizure-induced apoptosis in hippocampus (Fig. 6C). Neuronal apoptosis was also reduced in all three cortical areas sampled in p75 ${ }^{\text {NTR }}$ knock-out mice (Fig. 6C) compared with wild-type controls. Importantly, $\triangle \mathrm{DD}$ and $\mathrm{Cys}{ }^{259}$ mutant mice showed similar levels of protection to seizure-induced apoptosis as knock-out animals in all four brain areas investigated (Fig. 6D,E). Together, these data indicate that both the DD and TM Cys ${ }^{259}$ are required for neuronal death mediated by $75^{\text {NTR }}$ in vivo.

\section{Discussion}

While $\mathrm{p} 75^{\mathrm{NTR}}$ has emerged as an attractive therapeutic target for limiting neural damage in neurodegeneration and nerve injury, a detailed understanding of the physiological significance of its dis- tinct structural determinants is crucial for the identification of suitable drug targets. Here, we have tested the relevance of the p75 ${ }^{\text {NTR }}$ DD and the highly conserved TM residue Cys ${ }^{259}$ for the ability of $\mathrm{p} 75^{\mathrm{NTR}}$ to induce apoptosis in neurons of the CNS in vitro and in vivo using gene targeted mutant mice. The physiological importance of these determinants had been contested in some recent in vitro studies. Our results indicate that both the DD and TM Cys ${ }^{259}$ are required for neuronal death induced by p75 ${ }^{\text {NTR }}$ and its ligands.

Being the most prominent domain within its intracellular region, the DD has long been suspected to play a critical role in p75 ${ }^{\text {NTR }}$ physiology. Experiments in cultured cells devoid of p $75^{\text {NTR }}$, or derived from $775^{\text {NTR }}$ knock-out mice, have shown that $\mathrm{p} 75^{\mathrm{NTR}}$ constructs lacking the DD fail to rescue distinct p $75^{\text {NTR }}$-dependent functions, such as neurotrophin-induced apoptosis, which can otherwise be readily restored by wild-type constructs (Charalampopoulos et al., 2012). Before the present 
study, however, the in vivo relevance of the $\mathrm{p} 75^{\mathrm{NTR}} \mathrm{DD}$ for neuronal apoptosis had not been established. It should also be noted that other studies have implicated intracellular sequences distinct from the DD in cell death induced by $\mathrm{p} 75^{\mathrm{NTR}}$. In particular, a short peptide in the juxtamembrane region upstream of the DD, otherwise known as the "Chopper" domain, was proposed to be necessary and sufficient to initiate neuronal death (Coulson et al., $1999,2000)$. By introducing p $75^{\text {NTR }}$ constructs into peripheral neurons, these researchers identified a deletion mutant lacking the Chopper domain that was unable to mediate apoptosis even if it contained a DD. In addition, a deletion construct lacking the DD but containing the Chopper sequence was still able to induce apoptosis. In the Chopper mutant, it is possible that lack of juxtamembrane sequences compromised the activation of the DD homodimer or its ability to interact with downstream signaling components of the apoptosis cascade. The mechanistic basis of the effects attributed to the Chopper domain is unclear as the cell death reported was ligand independent, brought about constitutively by $\mathrm{p} 75^{\mathrm{NTR}}$ overexpression. Moreover, as the neurons that were used are known to express p $75^{\text {NTR }}$ endogenously at significant levels, it is uncertain whether the effects observed were dependent on endogenous $\mathrm{p} 75^{\mathrm{NTR}}$ expression. In this regard, it would be interesting to test whether sequences containing the Chopper domain are able to induce apoptosis in neurons from p $75^{\text {NTR }}$ knock-out or $\triangle$ DD mice. Our present results demonstrate that, when expressed endogenously and at physiological levels, the $\mathrm{p} 75^{\mathrm{NTR}} \mathrm{DD}$ is indeed required for ligand-induced apoptosis and seizure-induced cell death in neurons of the CNS. This indicates that other sequences in the $\mathrm{p} 75^{\mathrm{NTR}}$ intracellular domain are not sufficient for ligand-induced apoptosis in the absence of the DD.

The stoichiometry of $\mathrm{p} 75^{\mathrm{NTR}}$ has been debated for sometime. Studies using chemical cross-linking followed by denaturing gel electrophoresis have reported a main species of high molecular weight that has been attributed as receptor dimers or sometimes trimers. Species of even higher molecular weights were also observed in some studies. The use of chemical cross-linkers, particularly in whole cells or cell membranes, can lead to variable or artifactual results due to the unpredictable nature of the reaction as well as the possibility of spurious cross-linking to other cellular components. An early crystallography study of the extracellular domain of p $75^{\text {NTR }}$ in complex with NGF reported a monomeric receptor bound to a dimer of NGF (He and Garcia, 2004). However, this was later shown to be an artifact of deglycosylation during sample preparation, and subsequent studies confirmed a dimeric arrangement in the complexes of the extracellular domain of p $75^{\mathrm{NTR}}$ with either NGF or neurotrophin-3 (Aurikko et al., 2005; Gong et al., 2008). In addition, we have recently solved several NMR structures of signaling complexes of the p $75^{\text {NTR }}$ DD and showed that this domain forms low-affinity symmetric dimers in solution (Lin et al., 2015). Based mainly on evidence obtained from nonreducing gel electrophoresis, a recent study has argued that the main $\mathrm{p} 75^{\mathrm{NTR}}$ oligomer is a trimer (Anastasia et al., 2015). As it is well known, however, it is very difficult to determine molecular weights with any precision from the electrophoretic behavior of proteins in nonreducing gels. In particular, p75 ${ }^{\text {NTR }}$ has a rich network of disulfide bonds in its four cysteine-rich extracellular domains. This aspect of its tertiary structure remains intact in nonreducing gels and is likely to result in anomalous retardation through the gel matrix. The authors of this study found that a $75^{\mathrm{NTR}}$ construct with a mutation in the conserved TM cysteine failed to form "trimers" in nonreducing gels (Anastasia et al., 2015), a result that agrees with our earlier work showing that such mutant receptor is indeed monomeric in nonreducing gels (Vilar et al., 2009). However, the mechanisms by which a disulfide bond, which can link two but not three subunits, may induce a trimeric oligomer remained unclear. The same study also reported that overexpression of $\mathrm{p} 75^{\mathrm{NTR}}$ in wildtype hippocampal neurons increased the incidence of growth cone collapse and that this activity was maintained in the p $75^{\text {NTR }}$ cysteine mutant. The researchers interpreted this as evidence for the biological activity of p $75^{\mathrm{NTR}}$ monomers. As discussed above, there is always a danger in overinterpreting ligand-independent activities of overexpressed receptors. Also in this case, the presence of endogenous wild-type $75^{\mathrm{NTR}}$ in the transfected neurons might have influenced the results. Our present study has shown that in the absence of the TM cysteine i) neither mature NGF nor proNGF can induce conformational changes in $\mathrm{p} 75^{\mathrm{NTR}}$ intracellular domains, and ii) $\mathrm{p} 75^{\mathrm{NTR}}$ is unable to propagate apoptotic signals in response to neurotrophins in cultured neurons as well as in the epileptic brain. On the other hand, as we have shown previously, the lack of the TM cysteine does not affect the ability of p $75^{\text {NTR }}$ to regulate the RhoA pathway in response to myelinderived ligands (Vilar et al., 2009). Thus, it remains possible that the effects of $\mathrm{p} 75^{\mathrm{NTR}}$ overexpression on growth cone collapse, if confirmed in vivo, may require a different mechanism or structural determinants.

In conclusion, our results indicate a requirement for $\mathrm{DD}$ signaling by disulfide-linked dimers of $\mathrm{p} 75^{\mathrm{NTR}}$ for neuronal death induced by proneurotrophins and epileptic seizures. The new mouse models reported in this study will be useful to clarify the roles of the DD and TM Cys ${ }^{259}$ in other aspects of p $75^{\text {NTR }}$ physiology.

Note added in proof. While this paper was in press, Vilar and colleagues reported the NMR structure of the transmembrane domain of p75NTR showing it to be a dimer, not a trimer. Nadezhdin KD, García-Carpio I, Goncharuk SA, Mineev KS, Arseniev AS, Vilar M (2016) Structural basis of p75 transmembrane domain dimerization. J Biol Chem., doi/10.1074/ jbc.M116.723585.

\section{References}

Anastasia A, Barker PA, Chao MV, Hempstead BL (2015) Detection of p75NTR trimers: implications for receptor stoichiometry and activation. J Neurosci 35:11911-11920. CrossRef Medline

Aurikko JP, Ruotolo BT, Grossmann JG, Moncrieffe MC, Stephens E, Leppänen VM, Robinson CV, Saarma M, Bradshaw RA, Blundell TL (2005) Characterization of symmetric complexes of nerve growth factor and the ectodomain of the pan-neurotrophin receptor, p75NTR. J Biol Chem 280:33453-33460. CrossRef Medline

Charalampopoulos I, Vicario A, Pediaditakis I, Gravanis A, Simi A, Ibáñez CF (2012) Genetic dissection of neurotrophin signaling through the p75 neurotrophin receptor. Cell Rep 2:1563-1570. CrossRef Medline

Coulson EJ, Reid K, Barrett GL, Bartlett PF (1999) p75 neurotrophin receptor-mediated neuronal death is promoted by Bcl-2 and prevented by Bcl-xL. J Biol Chem 274:16387-16391. CrossRef Medline

Coulson EJ, Reid K, Baca M, Shipham KA, Hulett SM, Kilpatrick TJ, Bartlett PF (2000) Chopper, a new death domain of the p75 neurotrophin receptor that mediates rapid neuronal cell death. J Biol Chem 275:3053730545. CrossRef Medline

Feng D, Kim T, Ozkan E, Light M, Torkin R, Teng KK, Hempstead BL, Garcia KC (2010) Molecular and structural insight into proNGF engagement of p75NTR and sortilin. J Mol Biol 396:967-984. CrossRef Medline

Gong Y, Cao P, Yu HJ, Jiang T (2008) Crystal structure of the neurotrophin-3 and p75NTR symmetrical complex. Nature 454:789793. CrossRef Medline

He XL, Garcia KC (2004) Structure of nerve growth factor complexed with 
the shared neurotrophin receptor p75. Science 304:870-875. CrossRef Medline

Ibáñez CF, Simi A (2012) p75 neurotrophin receptor signaling in nervous system injury and degeneration: paradox and opportunity. Trends Neurosci 35:431-440. CrossRef Medline

Iulita MF, Cuello AC (2014) Nerve growth factor metabolic dysfunction in Alzheimer's disease and Down syndrome. Trends Pharmacol Sci 35: 338-348. CrossRef Medline

Lee KF, Davies AM, Jaenisch R (1994) p75-deficient embryonic dorsal root sensory and neonatal sympathetic neurons display a decreased sensitivity to NGF. Development 120:1027-1033. Medline

Lee R, Kermani P, Teng KK, Hempstead BL (2001) Regulation of cell survival by secreted proneurotrophins. Science 294:1945-1948. CrossRef Medline

Liepinsh E, Ilag LL, Otting G, ${ }^{* *}$ Ibáñez CF (1997) NMR structure of the death domain of the p75 neurotrophin receptor. EMBO J 16:4999-5005. CrossRef Medline

Lin Z, Tann JY, Goh ET, Kelly C, Lim KB, Gao JF, Ibáñez CF (2015) Structural basis of death domain signaling in the p75 neurotrophin receptor. Elife 4.

Nykjaer A, Willnow TE (2012) Sortilin: a receptor to regulate neuronal viability and function. Trends Neurosci 35:261-270. CrossRef Medline

Paxinos G, Franklin KBJ (2004) The mouse brain in stereotaxic coordinates. San Diego: Academic.

Roux PP, Barker PA (2002) Neurotrophin signaling through the p75 neurotrophin receptor. Prog Neurobiol 67:203-233. CrossRef Medline

Roux PP, Colicos MA, Barker PA, Kennedy TE (1999) p75 neurotrophin receptor expression is induced in apoptotic neurons after seizure. J Neurosci 19:6887-6896. Medline

Squire A, Verveer PJ, Rocks O, Bastiaens PIH (2004) Red-edge anisotropy microscopy enables dynamic imaging of homo-FRET between green fluorescent proteins in cells. J Struct Biol 147:62-69. CrossRef

Sykes AM, Palstra N, Abankwa D, Hill JM, Skeldal S, Matusica D, Venkatra- man P, Hancock JF, Coulson EJ (2012) The effects of transmembrane sequence and dimerization on cleavage of the $\mathrm{p} 75$ neurotrophin receptor by $\gamma$-secretase. J Biol Chem 287:43810-43824. CrossRef Medline

Troy CM, Friedman JE, Friedman WJ (2002) Mechanisms of p75-mediated death of hippocampal neurons: role of caspases. J Biol Chem 277:3429534302. CrossRef Medline

Underwood CK, Coulson EJ (2008) The p75 neurotrophin receptor. Int J Biochem Cell Biol 40:1664-1668. CrossRef Medline

Unsain N, Nuñez N, Anastasía A, Mascó DH (2008) Status epilepticus induces a TrkB to p75 neurotrophin receptor switch and increases brainderived neurotrophic factor interaction with p75 neurotrophin receptor: an initial event in neuronal injury induction. Neuroscience 154:978-993. CrossRef Medline

Vilar M, Charalampopoulos I, Kenchappa RS, Simi A, Karaca E, Reversi A, Choi S, Bothwell M, Mingarro I, Friedman WJ, Schiavo G, Bastiaens PI, Verveer PJ, Carter BD, Ibáñez CF (2009) Activation of the p75 neurotrophin receptor through conformational rearrangement of disulphide-linked receptor dimers. Neuron 62:72-83. CrossRef Medline

Volosin M, Song W, Almeida RD, Kaplan DR, Hempstead BL, Friedman WJ (2006) Interaction of survival and death signaling in basal forebrain neurons: roles of neurotrophins and proneurotrophins. J Neurosci 26: 7756-7766. CrossRef Medline

Volosin M, Trotter C, Cragnolini A, Kenchappa RS, Light M, Hempstead BL, Carter BD, Friedman WJ (2008) Induction of proneurotrophins and activation of p75(NTR)-mediated apoptosis via neurotrophin receptorinteracting factor in hippocampal neurons after seizures. J Neurosci 28 : 9870-9879. CrossRef Medline

VonDran MW, LaFrancois J, Padow VA, Friedman WJ, Scharfman HE, Milner TA, Hempstead BL (2014) p75NTR, but not proNGF, is upregulated after status epilepticus in mice. ASN Neuro 6: pii: 1759091414552185. CrossRef Medline 